\title{
SUPREME COUNCIL OF JUSTICE AND RELATED BODIES IN FOREIGN COUNTRIES: TYPOLOGICAL CLASSIFICATION
}

\author{
Serhii Khaliuk \\ Ph.D., Associate Professor, National Academy of Internal Affairs, Ukraine \\ e-mail: skhaliuk@ukr.net, orcid.org/0000-0003-1338-5117
}

\section{Summary}

In the modern context of transformations, the realm of social relations that determines the fundamentals of the functioning of the judiciary, particularly in recent decades, increasingly needs constitutional consolidation. This essentially concerns the bodies similar to the Supreme Council of Justice of Ukraine. The national legislation of Ukraine has well-defined provisions on the procedure of staffing, quantitative and organizational constitution of the Supreme Council of Justice in Ukraine. However, the world constitutional practice differently defines the status of bodies similar to the Supreme Council of Justice. Thus, the availability of bodies equal to the Supreme Council of Justice of Ukraine provides for an option of their grouping depending on the place or role, which the above bodies assume in the system of public authorities. That kind of classification aims to outline the general and specific features characterizing the legal status of the abovementioned bodies that will facilitate involving foreign practices into the national legislation of Ukraine and contribute to its improvement in terms of the functioning of the Supreme Council of Justice of Ukraine. Research methodology relies on using a set of methods that assist in achieving the scientific purpose. Such a set primarily consists of dialectical and system-structural methods, formal logic (analysis, synthesis, generalization) and comparative-legal one, which make it possible to handle the texts of statutory acts and doctrinal sources and help forward formulating the author's standpoint meeting the research purpose.

Keywords: judiciary, constitutional-legal status, judicial councils, classification features, European integration.

DOI: https://doi.org/10.23856/4521

\section{Introduction}

The constitutional consolidation of bodies accountable for ensuring the independence of the judiciary and self-reliance of judges when exercising their functional responsibilities and controlling the judicial field became peculiar to constitutions after the Second World War and the dissolution of the Soviet bloc. The vast majority of countries, which adopted constitutions in these historical periods, envisaged the establishment of the supreme magistrate bodies (of justice, the judiciary, judicial councils etc.). To settle the issue of judicial career management and courts administration, independent judicial bodies were formed (Albania, Armenia, Belgium, Brazil, Bulgaria, Denmark, Greece, Spain, Italy, Kazakhstan, Lithuania, Moldova, Poland, Portugal, Romania, USA, Turkey, France, Croatia, Sweden and others).

It seems impossible to study peculiarities of the status of all judicial councils within one scientific article because their number is huge in countries across the world. Therefore, there is a need to classify these bodies through specifying typological features that somewhat facilitates their further study and permits highlighting individual components of their legal status. Every judicial council emerged due to developing an inherent system that has deep roots in historical, 
cultural and social terms; nevertheless, all relevant councils have mutual challenges and follow general principles.

\section{Southern European and Northern European typological models of judicial councils}

One of the most prevalent classifications prescribes conventional division of judicial councils, which were formed in European countries, and includes two organizational models: northern (Sweden, Denmark, Norway) and southern (France, Italy, Spain, Portugal) (Mikuli P. 2010: 110, 125). Fundamental characteristics of the mentioned typological models of judicial councils, which are created and function in the modern Europe, are as follows: in terms of the Northern European Model, competencies of judicial councils include addressing organizational tasks concerning financing and logistical support of the judicial system; the Southern European Model also involves the participation of judicial councils in the selection, training, transfer of judges and bringing them to disciplinary responsibility (Voermans et al., 2003).

In general, the Southern European Model consolidates the constitutional status of judicial councils and the availability of a defining function - ensuring the independence of the judiciary (for instance, the provision of recommendations on judges' appointment (magistrates), the exercise of disciplinary powers towards judges (magistrates)). Therefore, the Northern European Model states that judicial councils have different powers in administration (supervision of court registration authorities, control over the volume of cases and their list, contribution to balanced legislation in the judiciary, etc.) and court management (for instance, housing, automation, recruitment, training etc.) and, in addition, play a crucial role in court budgeting (engagement in the budget generation, distribution, supervision and expenditure control etc.).

The key differentiation between the mentioned typological models of judicial councils is the historical background of establishment in different European regions. A reason for establishing judicial councils in the countries of Southern Europe was the need to guarantee the independence of the judiciary in the period after the Second World War and the overthrow of authoritarian governments. One of the means of ensuring the independence of judicial councils was the consolidation of their constitutional status (France, Italy, Portugal).

Indeed, judicial councils in Northern Europe, particularly in Denmark or Sweden, were established exclusively to accomplish the goals of improved administrative management and control over judicial budget and personnel. Sweden was the first country that created the Judiciary Council according to the 1975 Northern European Model. It is worth mentioning that Sweden has a unique system of public administration which is characterized by the constitutional tradition of functional decentralized delegation of powers from government ministries to independent administrative agencies.

At the same time, some European and American researchers stress that the basic powers of the relevant judicial councils rely on their a priori functions of the protection of the judiciary from political effects. Moreover, it is said that judicial councils "are created to isolate the functions of appointment, promotion and discipline of judges from the process of party policy through maintaining a particular level of accountability. Judicial councils are between contradictory edges: on the one hand - to permit judges to take the lead and, on the other hand-overall political control over appointments, job promotion and discipline" (Ortiz, 2017; Garoupa et al., 2009).

Ukrainian scientist S.V. Prylutskyi, who also distinguishes the Southern European and Northern European Models, has a similar standpoint towards the classification of bodies relevant to the Supreme Council of Justice of Ukraine. In his view, in many European countries, 
there is a tendency to borrow both models when creating/reforming judicial councils (justice councils) to accomplish a double goal: to protect judges from any intervention in their independence through appointment, job promotion or dismissal, and to meet demanding requirements of modern judicial administration. The above models can be called mixed (Prylutskyi, 2017: 11).

\section{The European model of judicial councils}

The research by European scientists M. Bobek \& D. Kosař, who have considered the formation of judicial councils in Central and East Europe, seems to be interesting. The authors have proposed "a European model" of judicial councils and put forward six key requirements for them. Thus, a judicial council shall have a constitutional status; a judicial council shall comprise at least $50 \%$ of the members and they shall be appointed by colleagues, i.e. other judges; a judicial council shall take final decisions on relevant powers, not only have advisory capacity; a judicial council shall have considerable authority on all issues concerning judge career, including selection, appointment, promotion, transfer, dismissal and disciplinary responsibility; a judicial council shall be headed by the president or head of the High (Supreme) Court; heads of the courts and their deputies are allowed to become a member of a judicial council. In the authors' opinion, the five models are widely used in Europe: the model of the Ministry of Justice, the judicial council model, the courts service model, hybrid models, and the socialist model.

The model of the Ministry of Justice is the most ancient. It states the Ministry of Justice plays a pivotal role both in judges' appointment and promotion and court administration and judicial procedure. This model is used in Germany, Austria, Czech, Finland and other countries. At the same time, it is misguided to believe that solely the Ministry of Justice deals with the matters of judges (appointment, promotion, dismissal, administration of courts etc.). Based on the model, such a statutory role is fulfilled by the President, parliament, judicial panels, ombudsman and others.

The judicial council model is a model which has an independent intermediary, i.e. a body that is between the judiciary and politically responsible persons in the executive branch of government and parliament. A judicial council is vested with considerable authority to appoint and promote judges and/or carry out disciplinary proceedings against judges. Moreover, judicial councils also can be granted authority to manage courts, approve courts' budges; however, this authority is minor towards authority over judges. There is that sort of model in Belgium, Bulgaria, France, Hungary, Poland, Portugal, Romania, Slovakia, Slovenia, and Spain. In addition, the authors indicate that not all judicial councils of the beforementioned countries of this model meet criteria of the "Eureopean model".

The model of courts service, compared to the above one, provides for the existence of an independent body that has powers in the management realm (supervision of judicial machinery, workload of judges, balanced distribution of cases and their consideration), court management (housing, automation, recruitment, training, etc.) and court budgeting. As opposed to judicial councils, court services play a limited role in the appointment and job promotion of judges (career) and don't perform disciplinary powers towards judges. Sometimes independent bodies - such as operating commissions for the appointment of judges to positions separate from the judicial service - are granted these powers. This model is available in Denmark, Ireland, Norway and Sweden.

The mentioned model comprises the Advisory Council of the Swedish National Courts Administration, which is a state body under the Government and deals with a service 
organization for Swedish courts, was founded in 1975. The jurisdiction of the court administration embraces overall coordination and general administrative issues under the framework of the Swedish judiciary system that involves maintaining courts, building leases, providing auditing services, matters of personnel management, education and the provision of information services, preparation of rules, recommendations and instructions. In particular, the National Courts Administration is responsible for the effective and relevant distribution of resources, assistance in extending cooperation both in the context of the Swedish judiciary system and between courts and other state bodies.

The research authors consider hybrid models as a model combining various components of the previous three in such a way that it is distinctly different from each of them. For instance, in the countries like England, Wales, Estonia, Hungary (since 2011), Iceland, Switzerland and in some European mini-states, these models contain sufficiently specific features that it is impossible to generalize them, and some common features cannot be distinguished. In one instance, there are judicial appointments commission engaged in selecting judges for a certain level of the judicial system, and the rest of judicial administration is entrusted to other body (England and Wales); in another case, in a country, there is established a judicial council which divides powers over judicial administration with other national-level body (Hungary, since 2011).

The socialist model of judicial administration provides for powers over judges and the judicial system as a whole in three institutions - General Prosecutor (prosecutor), Supreme Court and heads of courts - which also were controlled by a communist party. In other words, the communist party exercised control over the courts. The model's peculiarities varied depending on a specific country. The socialist model of judicial administration has no longer existed in Europe (Bobek et al., 2013).

\section{Other approaches to the classification of court councils}

By paying attention to the global level to find an alternative to the European model, there is an even greater variety of models of court administration. The European model of building judicial administration bodies is widespread in Latin America, due in part to the pressure from international actors, but also due to the influence of Latin Europe exercised in these countries. The Ministry of Justice models can be found in Canada or Japan. Socialist models of court administration still exist in China, Cuba, North Korea, Vietnam, and many ex-USSR countries. In addition to the five models of court administration one can find in Europe, specific models are available in many countries of the Middle East where religious institutions play a crucial role in judicial administration. In Africa, models of court administration are even more diverse, as they often combine colonial legacies with local specifics. From the European perspective, even the United States' model of court administration that puts a great emphasis on the democratic process - in particular, the election of judges- represents a distinct model that does not have an equivalent in Europe (Bobek et al., 2013).

As for the classification of bodies like the Supreme Council of Justice, depending on their personnel, they can be divided in those which consist of judges; which have mixed personnel; in which the majority is represented by courts. According to the structural criterion along with a mono-system organization of bodies of a judicial community, there are marked their poly-systemic and sophisticated systems that demonstrate a higher level of the specialization of bodies, the availability of several higher bodies. The need for structuring emerges in federal states as a dependence on the state-legal and administrative structure. 
Summing up the abovesaid, one can establish a direct dependence of the typological variety of the mentioned bodies on such conditions as the division of managerial and organizational powers between different judicial actors, essence and scope of tasks they are vested with and a country's historical-legal, political-economic and sociocultural context, its administrative structure. In addition, such bodies can have the features of state ones or don't have them in some cases; however, they are considered as an element of organizational-managerial activity in the judicial branch. By studying the genesis of the legal status of bodies that carry out judicial administration in foreign countries, one can find that the organizational system of the Supreme Council of Justice in Ukraine fully meets the European approach to building such bodies in countries with consolidated democracies, including France, Italy and Spain. In view of considerable differences in the judicial systems of European countries, Ukraine should use their experience, taking into account historical, national, mental features and traditions, model similarities of judicial systems, practical effects of the implemented reforms (Nor et al., 2015).

\section{Conclusions}

Consequently, having regard to the abovementioned characteristics, the author notes the Supreme Council of Justice is an independent type which is characterized by the available inter-type features. Thus, it stands to reason that historical background has become a basis for the development of statutory acts, which regulate the legal relations related to the status of the Supreme Council of Justice of Ukraine and relevant bodies of foreign countries, prevailing at the time of writing this article.

\section{References}

Bobek, M., Kosař, D., (2013) Global Solutions, Local Damages: A Critical Study in Judicial Councils in Central and Eastern Europe. Research Paper in Law.

Goda Ambrasaite - Balyniene (2015) Comparative analysis on the High Councils for Judiciary in the EU member states and judicial immunity.

Mikuli P. (2010) Rady sadownictwa w Europie. Krajowa Rada Sadownictwa. XX-lecie działalności. Warszawa, $432 \mathrm{pp}$.

Nor V., Bilostots'kyy S. (2015) Zakhyst nezalezhnosti sudiv i samostiynosti suddiv u diyal'nosti natsional'noyi rady sudivnytstva respubliky Pol'shcha: dosvid dlya Ukrayiny [Protection of the independence of courts and the independence of judges in the activities of the National Judicial Council of the Republic of Poland: experience for Ukraine] Visnyk L'vivs'koho universytetu. Seriya yurydychna, no. 61, pp. 442-451.

Pablo José Castillo Ortiz (2017) Councils of the Judiciary and Judges' Perceptions of Respect to Their Independence in Europe. Hague Journal on the Rule of Law, no. 9, pp. 315-336; Nuno Garoupa, Tom Ginsburg (2009) Guarding the Guardians: Judicial Councils and Judicial Independence. The American Journal of Comparative Law, no. 57, issue 1, pp. 103-134.

Prylutskyi S.V. Vyshcha rada pravosuddya - samostiynyy orhan sudovoyi vlady Ukrayiny!? (Aktual'ni pytannya novitn'oho konstytutsiynoho formatu) [The High Council of Justice is an independent body of the judiciary of Ukraine!? (Current issues of the latest constitutional format)]. Public Law, no. 4 (28), pp. 9-18.

Voermans W., Albers P. (2003) Councils for the Judiciary in EU Countries. Strasbourg. 